\title{
Seasonal Variability in the Distribution of Phytoplankton in Paracas Bay/Peru, as a Response to Environmental Conditions
}

\author{
Sonia Sánchez ${ }^{1}$, Nelly Jacobo ${ }^{1}$, Avy Bernales ${ }^{1}$, Augusto Franco ${ }^{1}$, Jorge Quispe ${ }^{2}$ and Georgina Flores ${ }^{3}$ \\ 1. Laboratory of Phytoplankton and Primary Production, Instituto del Mar del Peru, Chucuito, Callao 07001, Peru \\ 2. Functional Area of Research in Physical Oceanography, Instituto del Mar del Peru, Chucuito, Callao 07001, Peru \\ 3. Functional Area of Research in Chemical Oceanography, Instituto del Mar del Peru, Chucuito, Callao 07001, Peru
}

\begin{abstract}
During 2013-2015, a series of bio-oceanographic surveys was carried out in Paracas bay (13 $\left.50^{\prime} \mathrm{S}\right)$. This coastal habitat represents a transition between open ocean and continent. Changes in distribution and structure of phytoplankton community and presence of noxious algal blooms were evaluated. The vertical stability of water column was analyzed on transects of temperature, salinity and potential density. Stratification of the water column as well as other variables presented a seasonal behavior. The maximum values were recorded in summer and were directly related to the seasonal heat flux in surface layers of the bay, while in winter this stratification index was minimum. N/P ratios showed a seasonal variation with highest values in winter and lowest ones in summer. Silicate concentrations were minimum mainly during in spring due to high biological fixation. The dominance of diatoms was evident in winter and spring, with maximum abundances of $r$ strategists. The diversity and equitability indexes were low $(<3$ bits $^{*} \mathrm{cel}^{-1}$ and 0.31 , respectively). During summer, there was a greater contribution of oceanic species, with high concentrations of the dinoflagellate Prorocentrum cordatum; and a higher frequency of algal blooms (Akashiwo sanguinea, Heterosigma akashiwo, Eutreptiella gymnastica and Gonyaulax polygramma) in the coastal zone. Silicates and $\mathrm{pH}$ presented a significant correlation with diatom abundances in spring, whilst dinoflagellates were associated to warm and salinity conditions in summer. Weak correlations were found for potentially toxic dinoflagellates with temperature and for Pseudo-nitzschia group with silicates and phosphates.
\end{abstract}

Key words: HAB, transition zones, inshore ecosystem, Paracas bay-Peru, phytoplankton.

\section{Introduction}

Paracas bay $\left(13^{\circ} 50^{\prime} \mathrm{S}\right)$ is a semi-closed coastal boundary ecosystem, characteristic of which influences its physicochemical dynamics. It is influenced by coastal upwelling due to the constant entry of cold and oxygen deficient waters [1] and high discharge of Pisco River in summer months. These riverine discharges create a river plume, which may have a strong impact on the distribution on water properties, sediments and biota [2]. This bay is known for its high productivity, developing different biological-fishing resources; as well as, for the frequent presence of HAB (Harmful Algal Bloom) events, because of the pollution

Corresponding author: Sonia Sánchez, biologist academic, master, main research field: phytoplankton ecology. generated by the intense fishing factories activity, often producing hypoxia or anoxia events, causing mortality of these resources, especially of bivalve molluscs. Examples of this were the death of fish "liza" (Mugil cephalus) during April 1995 [3], possibly related to an HAB produced by Protoperidinium crassipes and Ceratium tripos; the mortality of scallop (Argopecten purpuratus) associated to the intense industrial activity of fishing plants and the develop of an HAB produced by the dinoflagellate Prorocentrum micans during June 2000 [4]; and the bloom dominated by the dinoflagellate Akashiwo sanguinea during the short period of April 11-14th, 2004, coincided with oxygen decrease and the death of fish [5].

The objective in this study is to describe the spatial-temporal variability of the composition, 
diversity and density of phytoplankton and to determine the environmental factors (example: transitional areas) that influenced the community structure.

\section{Materials and Methods}

Four campaigns were realized from Pisco river to Paracas bay $\left(13^{\circ} 40^{\prime}\right.$ to $\left.13^{\circ} 50^{\prime} \mathrm{SL}\right)$ in representative months for each season of the year during April 2013 (Fall), November 2014 (Spring), March 2015 (Summer) and July 2015 (Winter). Twenty-eight (28) stations were sampled during each campaign (Fig. 1). Water samples were collected with Niskin bottles at surface and bottom depths for phytoplankton, salinity, nutrients, oxygen, chlorophyll a and $\mathrm{pH}$ measurements. Temperature was measured with surface thermometer and CTD (Conductivity, Temperature and Depth Instruments), and water column currents with ADCP (Acoustic Doppler Current Profiler).

\subsection{Environmental Sampling}

Temperature and salinity were obtained at each station using a CTD-O SBE 19Plus V2, model 6265. The information was processed with "Seabird" software in the routine SBE-DataProcessing-Win32. Marine currents were registered with an ADCP-RDI Sentinel of $300 \mathrm{~Hz}$ fixed to the boat hull in drag mode, the registers of magnitude and direction in water column were made in levels (layers) from surface to bottom continuously as the boat moved using VMDAS, WINADCP software.

For oxygen analysis, surface and bottom water samples were collected using Winkler methodology [6] by iodometric titration. For chlorophyll a, surface water samples were collected in $200 \mathrm{~mL}$ bottles, 100 $\mathrm{mL}$ of water was filtered through $\mathrm{GF} / \mathrm{F}$ Whatman Filters $(0.75 \mu \mathrm{m})$ and then frozen. Unfreeze samples were extracted in $10 \mathrm{~mL}$ of $90 \%$ acetone during 3 hours, centrifuged for 10 minutes at $500 \mathrm{rpm}$ and the supernatant was read on the Turner Design fluorometer, model 10-AU following Yentsch and Menzel [7] and Holm-Hansen, et al. [8]. Nutrients concentrations were determined for surface and bottom using the UV-Visible spectrophotometric technique, following Strickland and Parsons [6]. pH values were determined by Dickson's method [9] for surface and bottom water samples using METTLER TOLEDO combined $\mathrm{pH}$ electrode model SEVEN MULTI.

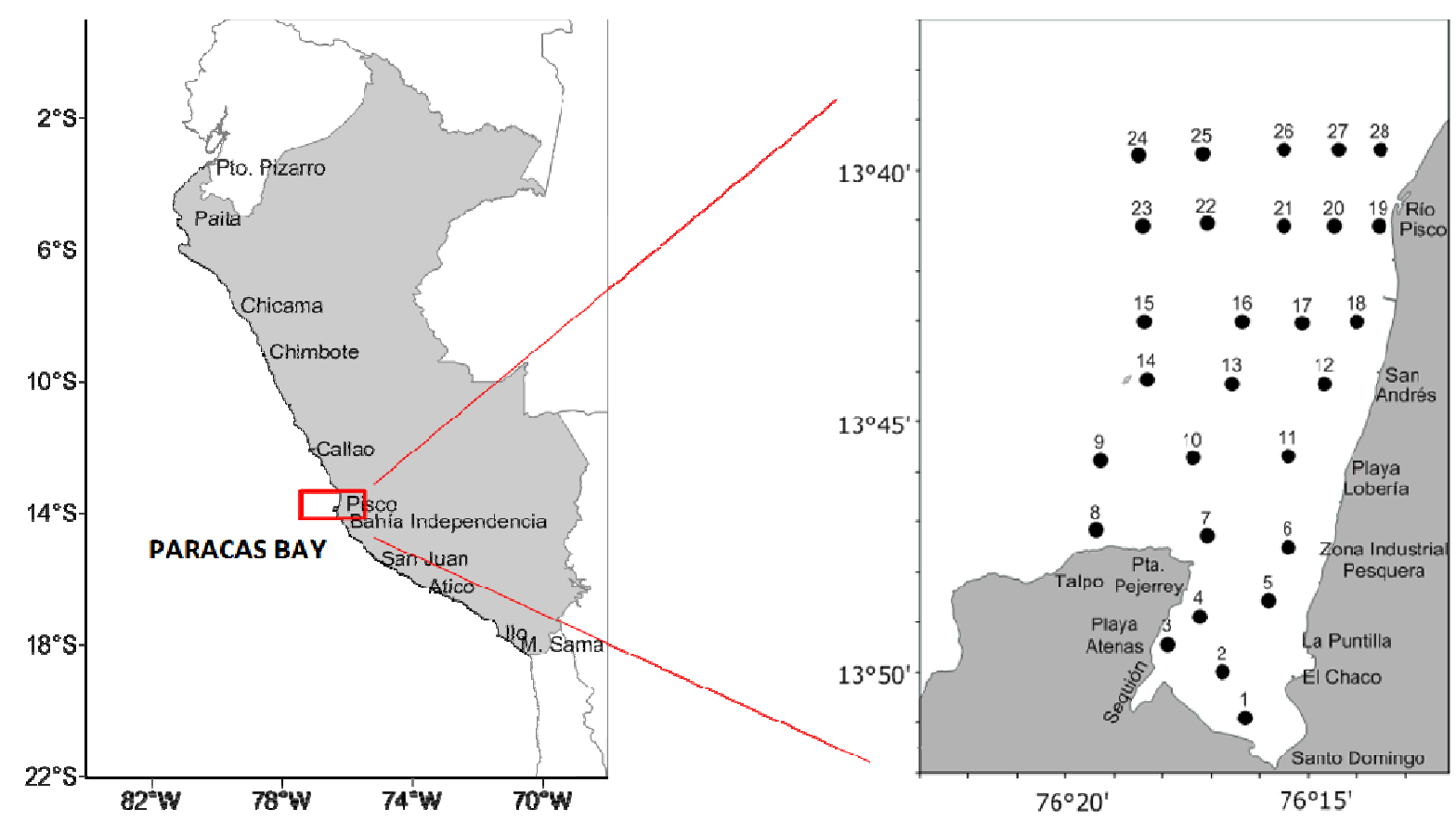

Fig. 1 Sampling map from Pisco River to Paracas bay. Black dots are the stations. 


\subsection{Phytoplankton Sampling}

Phytoplankton samples were collected at surface and bottom depth with a Niskin bottle. Samples were transferred to $100 \mathrm{~mL}$ dark bottles and fixed with $2 \mathrm{~mL}$ of a $2 \%$ buffered neutral formalin solution. For analysis, $50 \mathrm{~mL}$ subsamples were settled $(24 \mathrm{~h})$ and counted on an inverted microscope following Utermöhl methodology [10] giving the results in cell $\cdot \mathrm{L}^{-1}$.

\subsection{Index of Diversity, Similarity and Statistical Analysis}

Species diversity index (H'), similarity index (Bray-Curtis), NMDS (Non-metric Multidimensional Scaling) ordination and hierarchical clustering were used to analyze the phytoplankton community structure. Spearman's correlation coefficients between phytoplankton abundances and physicochemical parameters and multivariate statistical analysis (RDA (Redundancy Analysis)) were obtained with R program.

\section{Results}

\subsection{Environmental Conditions during Four Campaigns}

Different conditions were observed for each season. During April (fall), surface temperature was between 18.4 and $21.9^{\circ} \mathrm{C}$ (Fig. 2a). The lowest values were observed far from the coast in front of the Pisco river; on the other hand, the maximum values were recorded from the Pisco river zone along the coastal strip to Loberia beach, with a maximum nucleus to the west of it. Salinity presented values between 34.697 and 35.127 (Fig. 2e). A very homogeneous distribution was shown with the predominance of cold coastal waters. For November (spring), the temperature was recorded between 19 and $22{ }^{\circ} \mathrm{C}$ (Fig. 2b). The highest values were recorded front of Pisco river, decreasing towards the west, while, the minimum values were seen inside the bay. Salinity distribution was between 34.489 and 35.38 (Fig. 2f), which reflects the predominance of the cold coastal waters and the presence of mixed waters. The temperature distribution in the surface layer during
March (summer) is shown (Fig. 2c). Values between 18.1 and $25.3{ }^{\circ} \mathrm{C}$ were recorded, the highest temperatures were recorded at north of San Andres $\left(13^{\circ} 44^{\prime} \mathrm{LS}\right)$. A thermal gradient could be observed that separates the north zone from the south; while the lowest temperatures at south of San Andres, have more homogeneous values. Its maximum nucleus associated with the $25{ }^{\circ} \mathrm{C}$ isotherm was observed in northwest of the Pisco river, decreasing south parallel to the coast to San Andres west, while the minimum $\left(19^{\circ} \mathrm{C}\right.$ isotherm) was in the interior of the bay. Surface salinity registered values between 27.762 and 35.13 (Fig. 2g); two differentiated maximum salinity cores were observed, one in the interior of the bay and the other to the northwest in front of Punta Pejerrey; while the minimum cores were registered in the coastal strip between San Andres and Pisco river. During July (winter), surface temperature values between 18.6 and $19.6{ }^{\circ} \mathrm{C}$ were recorded (Fig. 2d). The highest temperatures were recorded in south of the Pisco river and in front of San Andres. Two cores of minimum temperatures $\left(18.8^{\circ} \mathrm{C}\right)$ were also observed, one to the west in a transitional area of San Andres and the other to the interior of Paracas bay with more homogeneous values. The distribution of salinity registered values between 35.01 and 35.234 (Fig. 2h); two maximum nuclei of salinity were observed, one in the interior of the bay and the other in transitional area of the Pisco river; while the minimum ones were registered towards the west in front of Lobería beach.

Two transitional areas were developed in the bay only during March 2015 (Fig. 2g): the first one in front of Pisco river, and the other in the middle south zone of the bay. Both were due to the convergence of different water masses with particular physical properties, and with maximum surface gradients of temperature, salinity and density. These conditions were not observed in the other three campaigns. In March 2015 (summer), maximum gradients were noted in the thermal distribution at surface of the order of $5{ }^{\circ} \mathrm{C}$ (Fig. 2c), these were generated by different physical processes 


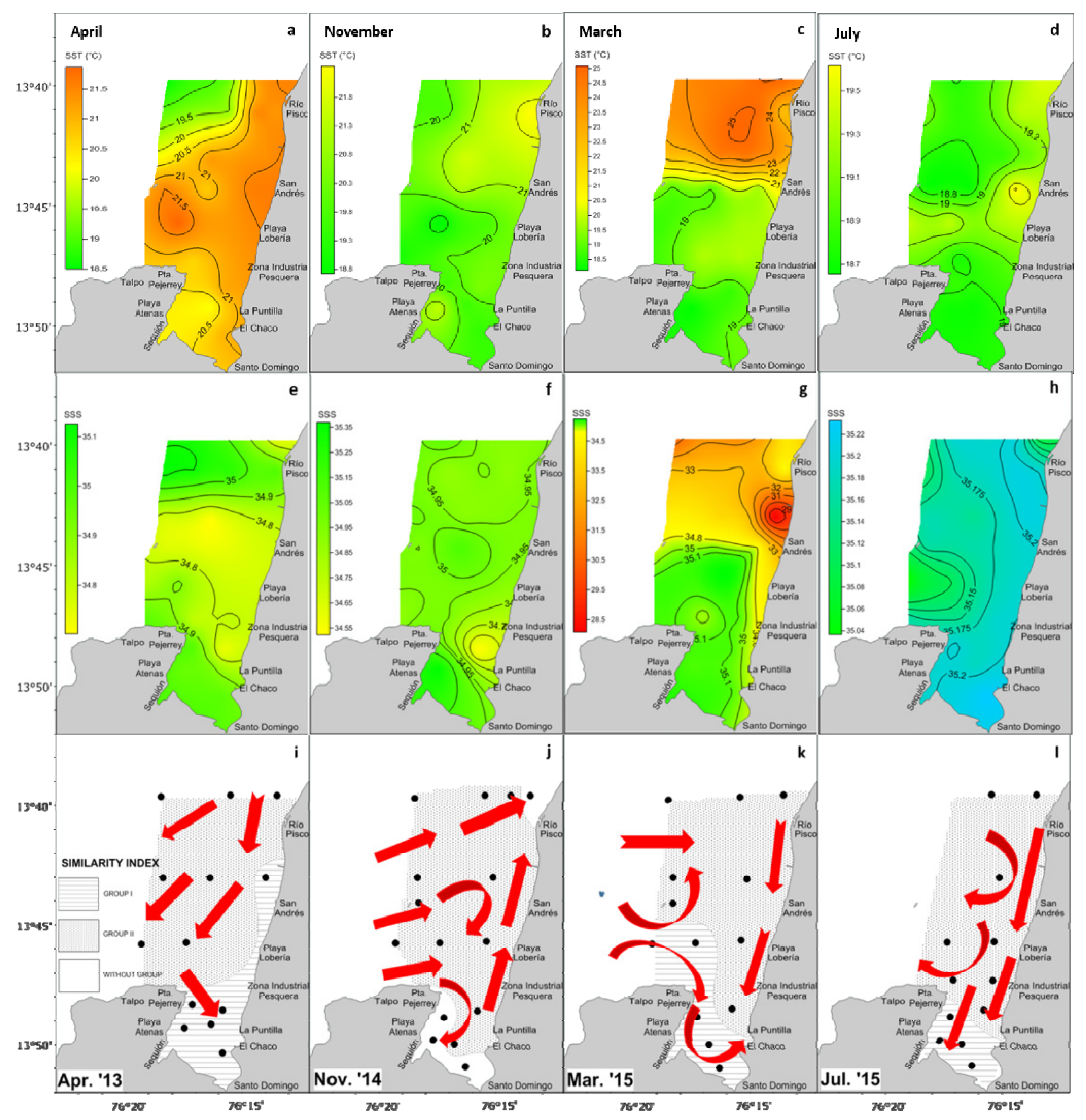

Fig. 2 Enviromental conditions (Sea surface temperature (a, b, c, d) and salinity (e, f, g, h), currents (i, j, k, l)) and indexes of similarity (Bray Curtis) in Paracas bay for the four periods.

and their mechanisms varied seasonally. In front of Pisco river, there was greater stratification than in the south zone, and transported flows towards the center of the bay were due to local wind effect.

The marine currents at surface level on a seasonal scale (Fig. 2i-1), determined the entrance of dominant flows coming from the south to the interior of the bay. Likewise, the projection of north and south direction flows parallel to the coast was observed, associated with the formation of turns towards the west favoring the retention of particulate material (i.e. phytoplankton). 


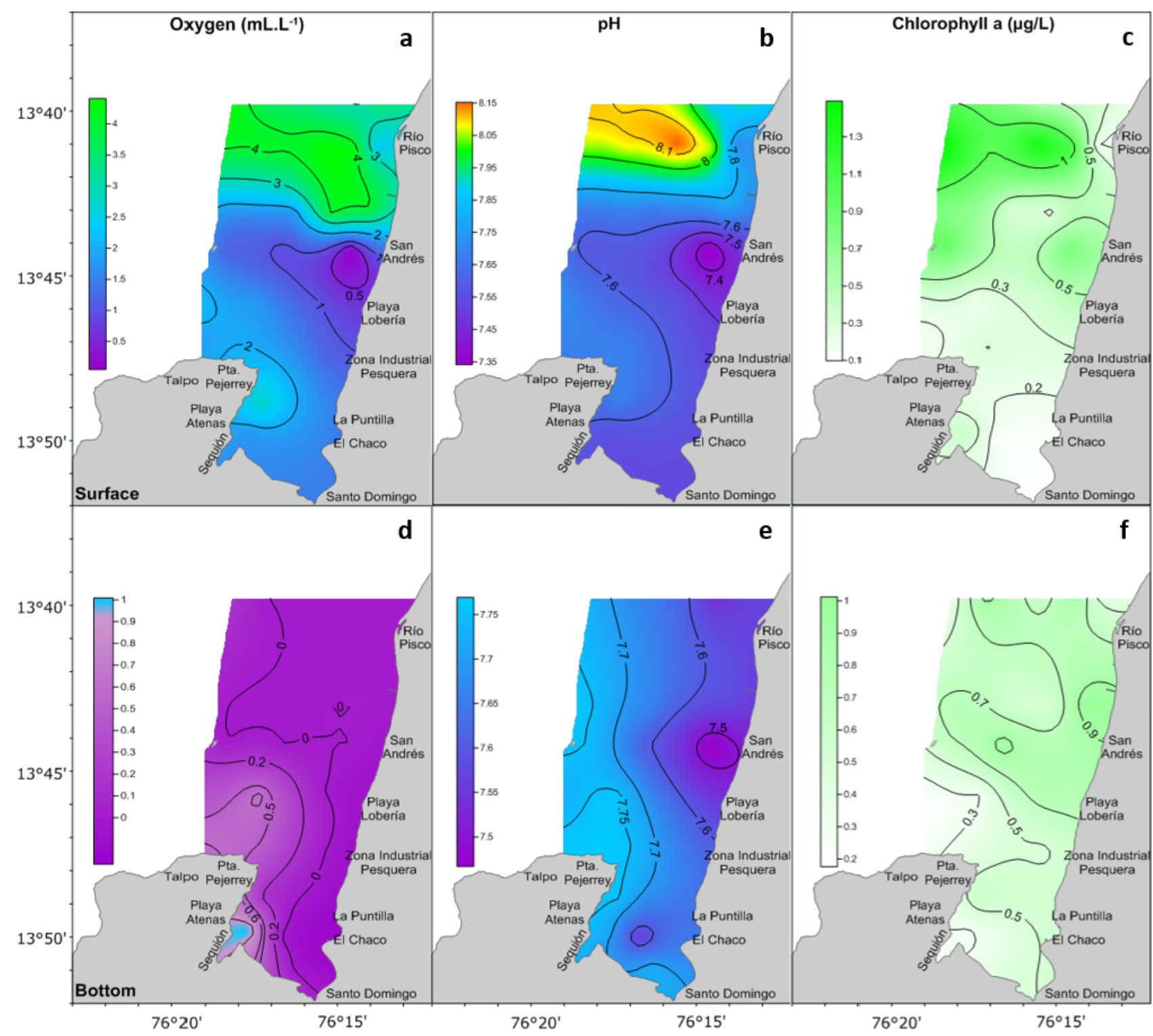

Fig. 3 Oxygen, pH and chlorophyll a at surface (a, b, c) and bottom (d, e, f) levels respectively in March (summer) conditions.

\subsection{Biochemical Conditions}

Surface oxygen in March (summer) showed concentrations between 0.00 and $4.47 \mathrm{~mL} \cdot \mathrm{L}^{-1}$. Concentrations below $4 \mathrm{~mL} \cdot \mathrm{L}^{-1}$ predominated throughout the study area. Values less than $2 \mathrm{~mL} \cdot \mathrm{L}^{-1}$ were located south of San Andres (Fig. 3a). pH values in surface had a range of 7.33 and 8.16 (Fig. 3b), showing same behavior as oxygen. Chlorophyll a surface concentrations were characterized by poor values $(<0.5 \mu \mathrm{g} / \mathrm{L})$ in most of the study area (Fig. 3c).
Oxygen at bottom level showed values of 0.00 and $1.75 \mathrm{~mL} \cdot \mathrm{L}^{-1}$, being a large extension in anoxic conditions, only in a small area in front of Talpo and Atenas beach, concentrations lower than $0.5 \mathrm{~mL} / \mathrm{L}$ were found (Fig. 3d). pH presented a range of 7.46 and 7.76, with a tendency to decrease which was associated with anoxic conditions (Fig. 3e). The distribution of chlorophyll a showed a range of 0.15 to $1.03 \mu \mathrm{g} / \mathrm{L}$. Most of the bay had values less than $0.5 \mu \mathrm{g} / \mathrm{L}$ (Fig. 3f).

Regarding the concentration of nutrients, it was recorded that phosphates on the sea surface ranged 
from 0.84 to $5.45 \mu \mathrm{M}$ with an average of $2.73 \mu \mathrm{M}$. Concentrations greater than $3.5 \mu \mathrm{M}$ predominated south of San Andres. Silicates range was 12.54 and $55.13 \mu \mathrm{M}$, showing high values $(>30 \mu \mathrm{M})$ in front of Santo Domingo and north of San Andres. Nitrates range was 0.00 to $4.27 \mu \mathrm{M}$. Values were less than $4 \mu \mathrm{M}$, indicating a nitrate deficit. Nitrites ranged from 0.00 to $1.19 \mu \mathrm{M}$, with a nucleus of $1 \mu \mathrm{M}$ found in front of Talpo.

At bottom level, phosphates presented a range of 1.52 to $8.01 \mu \mathrm{M}$, which increased with respect to the surface, values greater than $3.5 \mu \mathrm{M}$ were south of Pisco river to San Andres. Silicates showed values within the normal ranges. Nitrates showed a deficit in the entire study area, with values less than $5 \mu \mathrm{M}$. Nitrites were in the range of 0.05 and $2.58 \mu \mathrm{M}$, with an upward gradient distribution from the coast outward.

\subsection{Phytoplankton Community Distribution and Its} Response to Environmental Conditions

The highest abundances were observed in November 2014 (spring) at surface and bottom depths, registering maximum nuclei of $5.4 \times 10^{6}$ and $3.7 \times 10^{6} \mathrm{cell} \cdot \mathrm{L}^{-1}$ respectively, located at 6 and $5 \mathrm{~nm}$ from the littoral area outside the bay. Most diatoms belonging to $r$ strategy (ruderals) were the dominant species in total abundances of phytoplankton (Chaetoceros spp., Leptocylindrus danicus, Bacteriastrum delicatulum). Central diatoms with $\mathrm{r}$ strategy (Chaetoceros spp., Guinardia striata and Skeletonema costatum) were the most important in March 2015 (summer); pennant diatoms such as Amphiprora sp., Asterionellopsis glacialis, Cylindrotheca closterium, Thalassionema nitzschioides and some central ones like Leptocylindrus cf. minimus and S. costatum mainly characterized the community in April 2013 (fall); while, small diatoms with a high reproductive rate were recorded in July 2015 (winter). HAB densities reached their maximum values during summer 2015 and fall 2013. Prorocentrum micans, reached its highest concentrations in fall $\left(76 \times 10^{3}\right.$ cell $\left.\cdot \mathrm{L}^{-1}\right)$ within the bay;
Prorocentrum cordatum, was registered in March with $403 \times 10^{3} \mathrm{cell} \cdot \mathrm{L}^{-1}$ at $6 \mathrm{~nm}$ from the mouth of Pisco river, however, it reached a greater coverage in April. Finally, species of the genus Pseudo-nitzschia spp. reached concentrations less than or equal to $112 \times 10^{3} \mathrm{cell} \cdot \mathrm{L}^{-1}$ in winter 2015 in the central zone.

\subsection{Index of Diversity, Similarity and Statistical Analysis}

The maximum values of diversity index $\left(\mathrm{H}^{\prime}\right)$ were at the bottom layer in April and July $\left(\sim 3.5 \mathrm{Bits}^{\bullet} \mathrm{cell}^{-1}\right)$; while values below $2.5 \mathrm{Bits}^{\cdot}$ cell $^{-1}$ in surface, show active growth populations forming chains and typifying the first phase of succession. The maximum value was recorded in the central area of the study, between Pisco river and Paracas bay in winter (2.41 Bits $\cdot$ cell $\left.^{-1}\right)$, and besides, few dominant species were recorded, reflected in the low equitability index (0.31). The similarity index and NMDS showed a seasonality for whole campaign (Fig. 4).

The multivariate statistical analysis was done with RDA, to investigate relationships between the most abundant phytoplankton species (red lines) and the environmental variables (blue arrows) in Fig. 5. The eigenvalues obtained, revealed that first two axes of the RDA triplot explained $41 \%$ and $25 \%$ of the variation in the dataset, respectively. The first axis was mainly influenced by sea surface temperature and nitrites while second axis by $\mathrm{pH}$ and silicates (Fig. 5C). Highest abundances of diatoms as $B$. delicatulum, $L$. danicus, Proboscia alata f. indica, D. fragilissimus and Chaetoceros affinis (s5, s26, s31, s17 and s7 in Fig. 5C) occurred mainly in spring and were associated with low nutrient waters and high values of $\mathrm{pH}$ and oxygen, caused by spring bloom, excluding B. delicatulum, known as temperate species whose occurrence was due to positive temperature anomalies $\left(+1{ }^{\circ} \mathrm{C}\right)$. As there was not any correlation, in general, between salinity and biological data, the bay was classifying into three zones (north: facing the Pisco river, Central, South: within the bay itself), and a correlation analysis was 


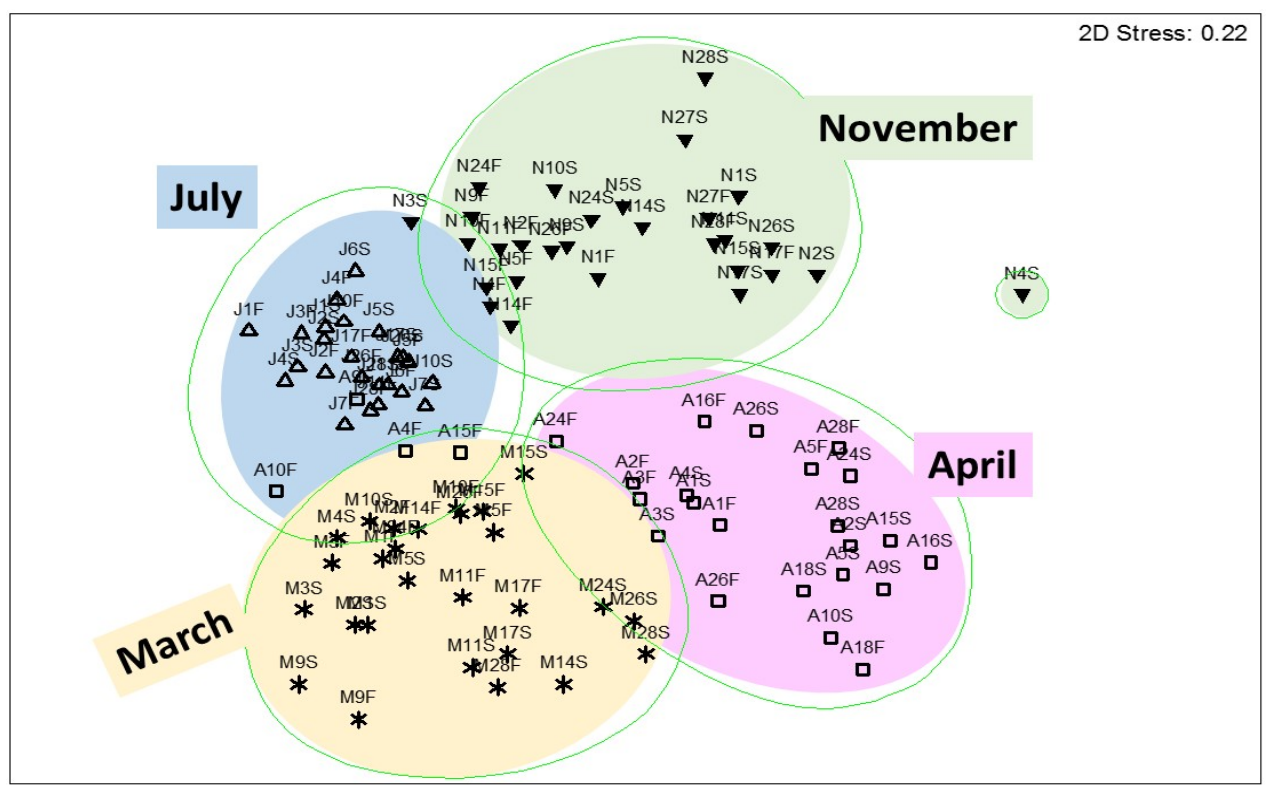

Fig. 4 NMDS ordination of four sampling periods based on phytoplankton species cellular densities (M: March; A: April; J:July; N:November; S:surface; F:bottom).

developed again, resulting in a significant correlation $(R=0.8)$ between salinity and dinoflagellates for the collection points located in the northern zone.

HAB dinoflagellates such as $P$. cordatum and $P$. micans (s55 and s54) were related with high availability of silicates (since there were not diatoms to fix this nutrient) and higher temperatures during summer-autumn period. Pseudo-nitzschia pungens (s34), a potentially toxic diatom, and central diatoms as Thalassiosira rotula (s43) and Th. anguste-lineata (s42) were associated with high values of nitrites and colder waters, mainly during winter period.

\section{Discussion}

During the study period in the Paracas bay, normal conditions were present, with some warm conditions for 2014 and 2015 according to official statements of ENFEN

(http://www.imarpe.pe/imarpe/lista.php?id_seccion=I 0166020000000000000000\&_pagi_pg=5). Only in March (summer), two transitional areas were developed in the bay: the first one in front of Pisco river, and the other in the middle south zone of the bay. Li, et al. [11] mentioned that a plume front could appear when the fresh water discharge was stronger than the tidal effect. Therefore, they found a transitional system affected by both the river plume and coastal upwelling; this could be the same case of the transitional area in the middle south zone.

Oxygen during summer showed high values for surface and anoxic values associated with the bottom layer. Surface values are elevated by absorption of the atmosphere and production by photosynthesis [12]. At bottom level, the bay exhibited a large extension of anoxic and hypoxic conditions. Aguirre, et al. [13] mentioned that this is the case of the bays of Peruvian coast, generally finding hypoxic conditions. Other studies in this bay showed the presence of anoxic conditions, in addition to the production of sulphides [3,4]. $\mathrm{pH}$ showed the lowest values near the coast, associated with the lowest oxygen content. Cabello, et al. [4] recorded low $\mathrm{pH}$ values associated with upwelling waters and organic contamination, accompanied by oxygen depletion that triggers oxide-reduction reactions. Chlorophyll a surface concentration was characterized by poor values for March. These values are for the bay. Jacinto, et al. [3] found values of up to $20 \mu \mathrm{g} / \mathrm{L}$ for April, and for May values of up to $14 \mu \mathrm{g} / \mathrm{L}$, 

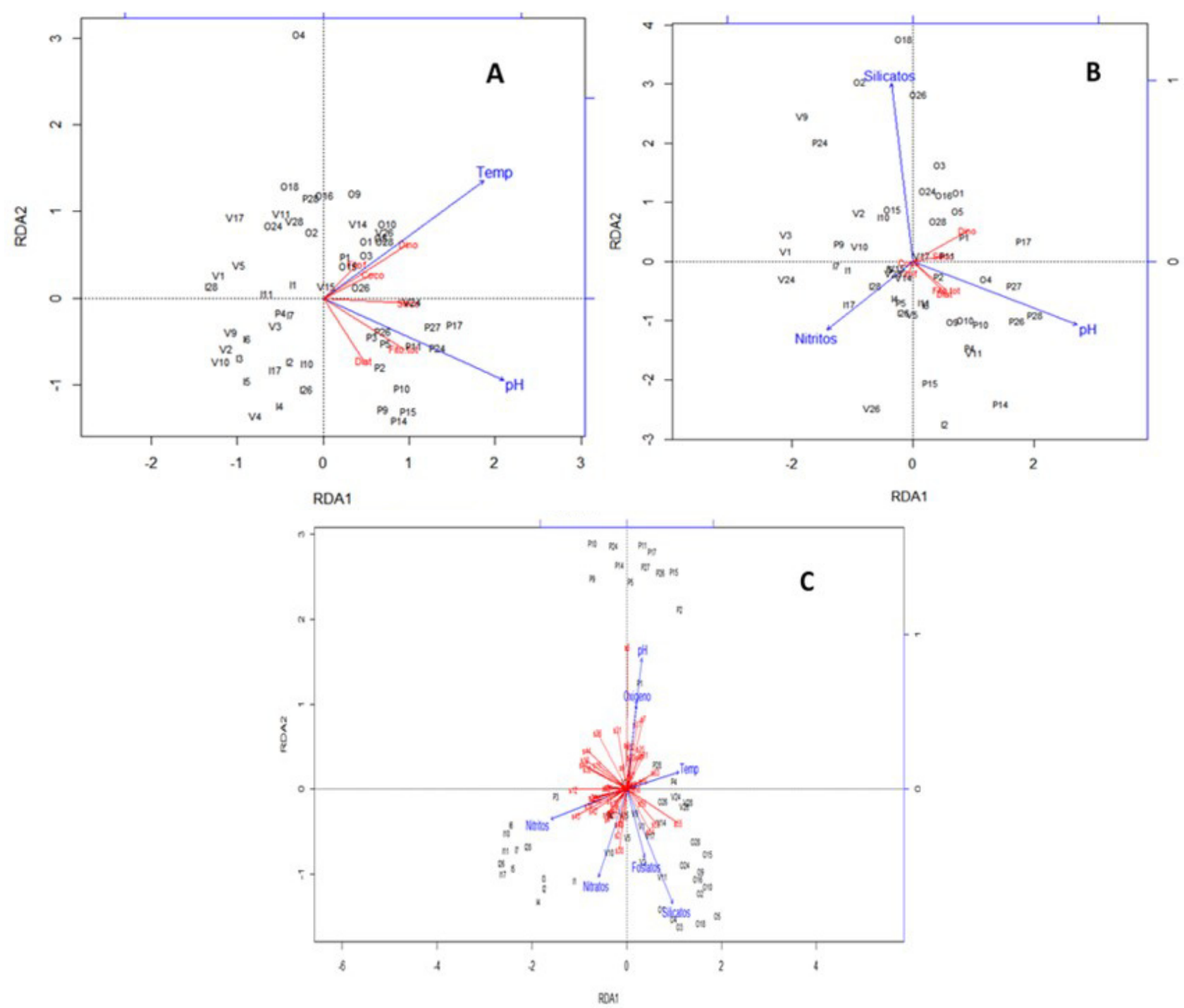

Fig. 5 RDA correlation triplots of principal groups of phytoplankton (red arrows) in surface and bottom layers (graphs A and $B$, respectively) in relation to environmental variables (blue arrows). Graph $\mathrm{C}$ shows the correlation triplot of the most abundant species in surface. The sampling stations and the seasons (V: summer; O: autumn; I: winter; P: spring) are in black.

with the highest concentrations within the bay. Yin, et al. [14] showed that during March, the interaction of winds and river discharge frequently provides nutrients, which increases primary production and decreases the periods of nitrogen limitation, results opposed to ours. However, Harrison, et al. [15] found low chlorophyll a concentration, it was not due to the increase of turbidity of the riverine plume, but it could be because of the increase in the vertical mix layer. The concentration of nutrients during the summer presented normal conditions for the bay, with the exception of nitrates which presented low values. Jacinto, et al. [3] found for May 1995 a very similar distribution of phosphates and silicates, as well as nitrate concentrations between 1 and $2 \mu \mathrm{M}$, related to low oxygen concentrations. Other studies indicate that river discharges provide nitrates and phosphates, but the shortage of nitrates is due to the physiological responses of phytoplankton. Then phosphates and not nitrates are found because phytoplankton is nitrogen-limited tended to take up nitrogen before phosphorus [14]. Harrison, et al. [15] found the same results in an estuarine plume, nitrate 
and ammonium reached undetectable concentrations occasionally in the top $4 \mathrm{~m}$, indicating that nitrogen most likely limited primary production on some days at this station.

The maximum abundances of phytoplankton were found in spring, with dominance in the stations outside the bay. Taylor, et al. [16] mentioned that the annual cycle of phytoplankton growth in many parts of the ocean is dominated by a dramatic population increase known as the spring bloom. Diatoms of $r$ strategy were the dominant species in the bay. Also during summer, diatoms like Chaetoceros spp., G. striata, L. danicus, $S$. costatum and Thalassionema spp. were the most important. Harrison, et al. [15] found that diatoms like S. costatum and Chaetoceros spp. dominated in terms of relative biovolume the river plume; in terms of species abundance, a small prasinomonad dominated the total cell numbers, followed by $S$. costatum and Chaetoceros spp. Jacinto, et al. [3] found the dinoflagellate Ceratium tripos as the most abundant species in May 1995 in the bay, but diatoms with high reproductive rates were also present, such as Chaetoceros spp. and Th. nitzschioides. Zhang, et al. [17] found in an estuarine environment during 2004-2010 diatoms as the dominant species (e.g. genera Skeletonema, Coscinodiscus, Chaetoceros, Nitzschia, Ditylum and Aulacoseira) except the year of 2009 (dominated by Spirulina spp.).

RDA results showed a first axis influenced by sea surface temperature and nitrites, and a second axis by $\mathrm{pH}$ and silicates. Sea surface temperature is an important factor, the increase of solar heating of the stratified surface layer results in faster growth rates [18], this being an important factor in the development of HABs. Highest abundances of diatoms occurred mainly in spring and were associated with low nutrient waters and high values of $\mathrm{pH}$ and oxygen. $\mathrm{Li}$, et al. [11] found phytoplankton on the sea side of the front could be $\mathrm{P}$ limited, $\mathrm{N}$ limited or not limited by $\mathrm{N}$ and $\mathrm{P}$. There was no evidence of Si limitation.

Paracas bay is a retention zone of phytoplankton and
HABs [19], extending their distribution when there is an increase in sea surface temperatures (summer or warm conditions). Species like $P$. micans, $P$. cordatum and Pseudo-nitzschia spp. develop HABs in the bay. The characteristic of semi-closed bay supports HAB events due to the cell transport from near shore waters to the bay, this can be explained by wind-driven water exchange, in combination with water column stratification, influx of cool bottom water, or the influx of warm surface water [20]. Also, Cabello, et al. [4] observed the presence of an HAB caused by the dinoflagellate $P$. micans, which was present before and during the mortality event. This algal bloom was associated with a slight increase in temperature. Sanchez, et al. [19] found high variability in number of potentially toxic species for Paracas bay during March 2013.

\section{Conclusions}

The phytoplankton in Paracas bay presents a change in a seasonal way, observable mainly during the summer; period in which the action of the discharge of the river and the coastal upwelling generate a river plume and a front in the middle zone of the bay. In addition to this, this period presented the presence of HABs. The predominance of $r$ strategy diatoms was observed for the entire study period. More information is required to be evaluated about the interaction of phytoplankton and environmental factors like wind, tidal effect, light limitation; and relation with small cell sized phytoplankton.

\section{References}

[1] Ledesma, J., Tam, J., Graco, M., León, V., Flores G., and Morón, O. 2011. "Caracterización de la Zona de Mínimo de Oxígeno (ZMO) frente a la costa peruana entre $3^{\circ} \mathrm{N} \mathrm{y}$ 14º, 1999-2009." Bol. Inst. Mar Perú 26: 49-57.

[2] Acha, E. M., Piola, A., Iribarne, O., and Mianzan, H. 2015. Plume Fronts. In Ecological Processes at Marine Fronts, 1st ed. Dordrecht, Heidelberg, London, New York: Springer, pp. 9-10. ISBN 978-3-319-15479-4.

[3] Jacinto, M. E., Martinez, C., Sánchez, S., Flores, G., and Pizarro, L. 1996. "Evaluación de la varazón y 
contaminación en la Bahía Paracas-Pisco.” Inf. Prog. Inst. Mar Perú 29: 1-47. (in Spanish)

[4] Cabello, R., Tam, J., and Jacinto, M. E. 2002. "Procesos naturales y antropogénicos asociados al evento de mortalidad de conchas de abanico ocurrido en la bahía de Paracas (Pisco, Perú) en junio del 2000.” Rev. Peru. Biol. 9 (2): 94-110, ISSN 1727-9933. (in Spanish)

[5] Kahru, M., Mitchell, B. G., Díaz, M., and Miura, M. 2004. "MODIS Detects a Devastating Algal Bloom in Paracas Bay." Peru. Eos. 85 (45): 465-72. doi: 10.1029/2004EO450002.

[6] Strickland, J., and Parsons, T. 1972. Practical Handbook of Seawater Analysis. Fisheries Board of Canada Ottawa, Bulletin, 167.

[7] Yentsch, C. S., and Menzel, D. W. 1963. "A Method for the Determination of Phytoplankton Chlorophyll and Phaeophytin by Fluorescence." Deep-Sea Res. 10: 221-31.

[8] Holm-Hansen, O., Lorenzen, C., Holms, R., and Strickland, J. 1965. "Fluorometric Determination of Chlorophyll.” J. Cons.perm.int Explor. Mer. 30: 3-15.

[9] Dickson, A. 1993. "pH Buffers for Sea Water Media Base on Total Hydrogen Ion Concentration Scale." Deep Sea Research 40: 107-18.

[10] Intergovernmental Oceanographic Commission of CUNESCO. 2010. Microscopic and Molecular Methods for Quantitative Phytoplankton Analysis, edited by B. Karlson, C. Cusack, and E. Bresnan, Paris: UNESCO, p. 55.

[11] Li, Q., Zhou, W., Chen, Y., and Wu, Z. 2018. "Phytoplankton Response to a Plume Front in the Northern South China Sea." Biogeosciences 15: 2551-63.

[12] Zuta, S., and Guillén, O. G. 1970. "Oceanografía de las aguas costeras del Perú.” Bol. Inst. Mar Perú 2: 157-324. (in Spanish)

[13] Aguirre, A., Jean, F., Thouzeau, G., and Flye-Sainte-Marie, J. 2016. "Effects of Progressive Hypoxia on Oxygen Uptake in Juveniles of the Peruvian
Scallop, Argopecten purpuratus (Lamarck, 1819).” Aquaculture 451: 385-9.

[14] Yin, K., Goldblatt, R., Harrison, P., St. John, M., Clifford, P., and Beamish, R. 1997. "Importance of Wind and River Discharge in Influencing Nutrient Dynamics and Phytoplankton Production in Summer in the Central Strait of Georgia.” Mar. Ecol. Prog. Ser. 161: 173-83.

[15] Harrison, W. P., Clifford, P. J., Cochlan, W. P., Yin, K., St. John, M. A., Thompson, P. A., Sibbald, M. J., and Albright, L. J. 1991. "Nutrient and Plankton Dynamics in the Fraser River Plume, Strait of Georgia, British Columbia." Mar. Ecol. Prog. Ser. 70: 291-304.

[16] Taylor J. R., and Ferrari, R. 2011. "Shutdown of Turbulent Convection as a New Criterion for the Onset of Spring Phytoplankton Blooms." Limnol. Oceanogr. 56 (6): 2293-307.

[17] Zhang, Y., Yu, J., Jiang, Z., Wang, Q., and Wang, H. 2015. "Variations of Summer Phytoplankton Community Related to Environmental Factors in a Macro-Tidal Estuarine Embayment, Hangzhou Bay, China." J. Ocean Univ. China (Oceanic and Coastal Sea Research) 14: 1025-33. doi: 10.1007/s11802-015-2483-6.

[18] Ralston, D., Keafer, B., Brosnahan, M., and Anderson, D. 2014. "Temperature Dependence of an Estuarine Harmful Algal Bloom: Resolving Interanual Variability in Bloom Dynamics Using a Degree-Day Approach.” Limnol. Oceanogr. 59 (4): 1112-26.

[19] Sanchez, S., Bernales, A., Delgado, E., Chang, F. C., and Jacobo, N. 2017. "Variability and Biogeographical Distribution of Harmful Algal Blooms in Bays of High Productivity off Peruvian Coast (2012-2015)." J. Environ. Anal. Toxicol. 7: 530. doi: 10.4172/2161-0525.1000530.

[20] Berdalet, E., Montresor, M., Reguera, B., Roy, S., Yamazaki, H., Cembella, A., and Raine, R. 2017. "Harmful Algal Blooms in Fjords, Coastal Embayments, and Stratified Systems: Recent Progress and Future Research." Oceanography $30 \quad$ (1): 46-57, https://doi.org/10.5670/oceanog.2017.109. 